\title{
АВАРИИ ПРИ БУРЕНИИ БОКОВЫХ СТВОЛОВ СКВАЖИН ПЕРЕВОДИМЫХ ИЗ БЕЗДЕЙСТВУЮЩИХ В ДОБЫВАЮЩИЕ
}

\author{
К. В. Антонов, Д. Д. Жумабаев, А. П. Грабовская, \\ Башкирский государственный университет, г. Уфа, Башкортостан, Россия,
}

\section{DOI: https://doi.org/10.31435/rsglobal_conf/30042021/7527}

\begin{abstract}
The paper presents materials on drilling side wells in which accidents occurred. The process of eliminating accidents is shown in detail step by step, and the actions that were taken in this case, which allows us to judge the effectiveness of the measures taken to eliminate accidents. The material presented in the work on drilling sidetracks demonstrates the complexity and responsibility for each action in which it is possible not only to achieve the desired result in the process of drilling and work to eliminate the accident, but also in case of deviation from the planned plan or work program, it is possible to complicate the situation. This factual material can be quite clearly used in the educational process, in the preparation of specialists of the appropriate profile.
\end{abstract}

Keywords: well, face, drill tool, milling cutter, shank, circulation, accident, tack, flushing, layout, transfer, nipple, bell, load, torque, rotor.

Успешность строительства скважин требует от исполнителей работ глубоких профессиональных знаний и навыков, а ликвидация аварий еще и богатый практический опыт работы в данном сегменте. Быстрота ликвидации аварий во многом определяет техническое и технологическое оснащение буровой установки, квалификационный и профессиональных уровень буровой бригады, уровень профессиональной подготовки инженерно-технических специалистов имеющих отношение к сооружению скважины. Но не смотря на все допустимые благоприятные обстоятельства, аварии при строительстве скважин все же встречаются и причины их самые разные.

При бурении глубоких скважин выделяют четыре группы аварий: обрывы труб и породоразрушающего инструмента; развинчивание труб и породоразрушающего инструмента; прихваты труб и породоразрушающего инструмента; падение забойного двигателя, труб и посторонних предметов в скважину.

Обрывы могут происходить в бурильных, обсадных и колонковых трубах. Причинами обрывов бурильных труб является износ их поверхности, износ или низкое качество резьбовых соединений и большие нагрузки, создаваемые на колонну бурильных труб в результате осложнений в процессе бурения (обвалы пород, прихват, затяжки инструмента и др.).

Падение посторонних предметов в скважину является следствием халатности буровой бригады, если устье скважины не закрыто заглушкой (пробкой) во время профилактических и ремонтных работ.

Развинчивание бурильных труб наблюдается во время спуска, при недостаточной затяжке резьбовых соединений или при сильном износе.

Достаточно распространенными и довольно сложными авариями являются прихваты труб и породоразрушающего инструмента. В этой группе выделяют следующие виды аварий: прихваты породоразрушающего инструмента и колонковых труб; прихваты бурильных труб; прихваты обсадных труб.

Прихваты могут быть вызваны различными причинами. Прихваты часто возникают в результате геологических осложнений: обвалы стенок скважин, поглощения промывочной жидкости и др. Они могут происходить и по технологическим причинам в результате зашламования скважины, сужения ее ствола, наличия толстой и липкой фильтрационной корки на стенках скважины. Кусочки металла, оставшиеся в стенках скважины от предыдущих аварий, могут быть также причинами прихватов бурового инструмента [1].

Для полноты восприятия технических и технологических операций и работ, выполняемых в процессе строительства скважин и ликвидации аварий, рассмотрим пошагово аварии и последовательность их ликвидации произошедших на соответствующих этапах строительства бокового ствола скважины № 52 КРК и скважины № 223 БГН. 
При фрезеровании «окна» в обсадной колонне $146 \times 8,5$ мм скважины № 52 КРК, произошел слом фрезера ФР-124 (фрезер расширяющий). Начало фрезерования «окна» в обсадной колонне на глубине 2381 м, в качестве промывочной жидкости использовалась техническая вода удельного веса 1,17 г/ $\mathrm{cm}^{3}$. После фрезерования до глубины 2384,5 м механическая скорость снизилась до ноля. После подъема КНБК с фрезами было выявлено катастрофическое разрушение наконечника фрезы ФДУ-124/3. Спустили КНБК с новыми фрезами, на забое была попытка продолжить фрезерование на разных режимах (40 - 80 тс - для анализа нагрузки на фрезер) однако проходка не появилась и углубиться не удалось. После подъема КНБК на наконечнике фрезы, на всех резцах нулевой угол атаки, предположительно разрушенными резцами предыдущего фрезера, находившимися на забое. При повторном спуске аналогичной КНБК с новым фрезером ФДУ-124/3 и старым фрезером ФР-124 в начале фрезерования при нагрузке 20 кН произошел слом фрезы по ниппелю.

Для ликвидации аварии произвели спуск и наворот колокола на «голову» фрезы, подняли фрезу и произвели осмотр в плоскости излома. По материалам визуального осмотра комиссия пришла к выводу, что излом произошел в результате усталостного слома металла.

Спустили магнит и очистили забой от металла, промыли скважину, в качестве промывочной жидкости использовалась техническая вода удельного веса 1,17 г/см ${ }^{3}$.

Сменили КНБК спустили инструмент, проработали интервал «окна» и углубились на 15 м.

Собрали КНБК спустили до забоя с проработкой, промыли скважину 3 цикла и продолжили бурение.

В интервале 2399,5 - 2864,0 м бурение скважины происходило без осложнений.

При проработке ствола скважины (режим проработки: нагрузка 0-3 тн, расход бурового раствора 8,0 - 8,5 л/сек, давление - 78 - 98 атм) перед спуском хвостовика на глубине 2864,0 м вырос момент на роторе. После остановки вращения ротора инструмент поднять от забоя не удалось. Попытки расхаживания до 10 тн сверх веса бурильного инструмента при подъеме (52 тн) результата не дали. Инструмент освободили после закачки вязко-упругой смеси (ВУС) с повышенным содержанием смазывающей добавки и приложения усилия до 90 тн. В процессе подъема инструмента в эксплуатационной колонне на глубинах 1350 м, 1330 м, 1278 м, 1275 м отмечались затяжки инструмента до 5 - 8 тн. После прокачки ВУС и расхаживания инструмента продолжили подъем. После подъема на фрезере ФР-123 были обнаружены следы от металла.

При расследовании аварии было установлено, что проработка ствола скважины производилась с нарушением. В нарушение плана работ на спуск и цементирование хвостовика не в полном объеме произведена проработка ствола скважины от «окна» до забоя. По данным геолого-технологических исследований (ГТИ) не были проработаны интервалы 2360 - 2407 м, 2419 - 2426 м, 2429 - 2454 м, $2486-2494$ м, 2513 - 2623 м, 2642 - 2839 м, что с высокой степенью вероятности позволяет утверждать о причине аварии - прихвате бурильного инструмента. Непроизводительное время, затраченное на ликвидацию аварии и подготовку ствола скважины к продолжению бурения, составило 67 часов.

После заливки хвостовика и истечения времени ожидания затвердевания цемента в скважине № 223 БГН произвели нормализацию 114 мм хвостовика до глубины 3830 м, промыли скважину в течение 2,5 часов и начали подъем компоновки. При подъеме на глубине 3340 м произошла затяжка до 70 тн, инструмент потерял подвижность. При попытке восстановления циркуляции поднимали давление до 200 атм, циркуляцию восстановить не удалось. Расхаживание инструмента производилось с нагрузкой до 57 тн и разгрузкой до нуля тонн. При очередной натяжке вверх до 67 тонн произошло снижение веса инструмента и инструмент пошел вверх. После подъема обнаружили, что произошел слом НКТ-60 по телу. Подняли муфту НКТ с отломанной ниппельной частью. «Голова» представлена телом НКТ (внутренний диаметр - 50 мм) и находится на глубине 2149 м. В скважине осталось: долото У-95РИС - 0,13 м + переводник Н 3-66 × Н 3-66 - 0,47 м + В3Д Д-75 - 5 м + переводник Н 3-66 × М НКТ $60-0,47$ м + обратный клапан - 0,45 м + НКТ $60-1187,6$ м.

Завезли аварийный инструмент и собрали КНБК: колокол 114 ЛК 80-55 Мз-76 Ø с заводным языком высотой 30 мм $-0,64$ м + переводник Мз86×Н376 Øвн 32 мм, Ø нар $105-$ 0,28 м + СБТ $73386-417,76$ м СБТ $89386-1224,93$ + переводник Мз102ХНз86 - 0,45 м + СБТ 89 3-102 - 497,05 м + квадрат 7,0 м глубина составила 2148,11 м - «голова» оставленной в скважине компоновки. 
Спустили инструмент до глубины 2139 м, восстановили циркуляцию при расходе

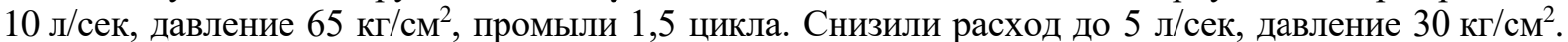

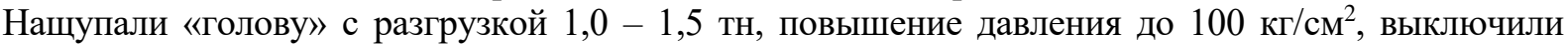
насос. Приподняли и отвернули квадрат, продули, завернули вновь с докреплением. Проверили вес: при движении вверх - $46-47$ тн, при движении вниз $32-33$ тн, при вращении $38,1-38,3$ тн, момент 3,5 - 4,0 кН·м. С вращением 12 об/мин дошли до «головы», навернулись до момента 5 кН·м. Проверили натяжкой до 50 тн. Разгрузили до 47,5 тн, отворот в несколько этапов с подтягиванием до 47,5 - 48,0 тн. Сделали 30 оборотов, максимальный момент 5,5 кН·м. Проверка веса на подъем показала увеличение веса до 48,5 - 49,0 тн, то есть увеличение на 1,5 - 2,0 тн. Захватили колоколом НКТ-60 и подняли 20 труб длиной 203,35 м. «Голова» оставшихся в скважине труб находится на глубине 2351,46 м, представлена муфтой НКТ $60 \varnothing 73$ мм. Собрали КНБК с колоколом: колокол К 95 - 60/122 - 0,77 м + СБТ 73 3-86 - 189,94 м СБТ 89386 1224,93 м переводник Мз102ХНз86 - 0,45 м + СБТ 89 3-102 - 935,82 м. Спустили инструмент на глубину 2344 м, восстановили циркуляцию при расходе 7 л/сек давление 50 кг/см², промыли 1,5

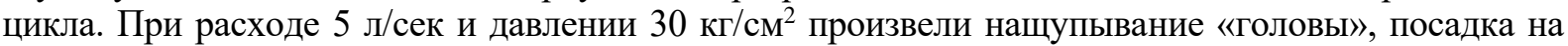
1,5 тн, роста давления не наблюдалось. Отвернули квадрат, навернули трубы СБТ-89, произвели проверку веса и момента: вес на подъем $52 \mathrm{TH}$, вес на спуск 34,5 тн, момент холостой 4,5 кН·м. Выполнили наворот на «голову» до момента 5,6 кН·м. Проверили соединение натяжкой до 63,11 тн собственного веса на подъем. Произвели посадку инструмента на клинья под натягом 16 тн и спустили геофизический прибор МЛМ + ГК Ø 42 мм. По записи прибор встал на глубине 2351 м, то есть на 5 м ниже колокола. Подняли прибор, натянули колонну до 60 тн (на 8 тн выше собственного веса на подъем СБТ) - прибор дошел до глубины 2489 м; подняли прибор и натянули до 67,5 тн (на 15,5 тн выше собственного веса на подъем СБТ) - прибор дошел до глубины 2489 м. Прибор МЛМ + ГК подняли и спустили прихватоопределитель длиной 0,5 м Ø 45 мм. Прихватоопределитель встал на глубине 2489 м. Отвернули с натяжкой 5 тн на подъем, свой вес 52 тн. Убрали СБТ 89 3-102, навернули квадрат. Взвешивание на подъем - 56 тн, на спуск 37,5 тн, при вращении 44,4 тн, момент 5,0-5,5 кН·м.

Навернули с моментом до $7 \mathrm{\kappa H} \cdot \mathrm{m}$; отвернули с натяжкой $63 \mathrm{TH}, 39,5$ оборотов с моментом до 10 кН·м (кратковременно до 12 кН·м) - отвернулись. Вес на подъем 56 тн, то есть собственный вес на подъем. Повторили операцию в тех же режимах, после отворота вес 56 тн. Приняли решение навернуться и рвать на подъем. Навернулись, поэтапно повышая нагрузку от 70 тн по 5 тн, произвели отрыв при нагрузке 83 тн. Подняли НКТ-60 - 13 труб длиной 131,83 м, «голова» на глубине 2482 м, представлена муфтой диаметром 73 мм. Собрали КНБК: колокол 114 ЛК 80-55 Мз-76 Ø Мз86ХНз76 Ø вн 32 мм, Ø нар $105-0,28$ м + СБТ 73 3-86 - 417,76 м + СБТ 89 3-86-1224,93 м + переводник Мз102 ХНз86 - 0,45 м + СБТ 3-102 - 834,61м + квадрат 3,0 м итого 2481 м. Спустили с докреплением, промыли, при нащупывании «головы» давление возросло с $30 \mathrm{kr} / \mathrm{cm}^{2}$ до 100 кг $/ \mathrm{cm}^{2}$. Проверили вес на подъем - 56-57 тн, на спуск 38 тн, при вращении 45 тн, момент холостой 5,5 кН·м. Наворот до 7,0-7,5 кН·м, при отвороте вес 62-60 тн при моменте 8,08,5 кН·м происходит срыв. Попытались 3 раза, на четвертом сработали на отрыв при 75 тн, произошел отрыв, вес на подъем 56-57 тн (собственный вес). Подняли, результат отрицательный, есть следы работы колокола на муфте.

Собрали КНБК: К 95 (90) - 60/122 - 0,64 м + СБТ 73 3-86 - 417,76 м + СБТ 89 3-86 1224,93 м + переводник Мз102 ХНз86 - 0,45 м + СБТ 89 3-102 - 834,61 м + квадрат 3,0 м всего 2481 м. Спустили до глубины 2481 м. Проверка веса, наверх 56-57 тн, вниз 38 тн, момент холостой 5,5 кН·м, навернули до момента $7 \mathrm{\kappa H} \cdot \mathrm{M}$, натяжка до $70 \mathrm{TH}$, отворот на $60 \mathrm{TH}$, срыв через10 оборотов, вес наверх 56-57 тн. Наворот до 7,5 кН·м, натяжка до 70 тн, отворот при весе $60 \mathrm{TH}$, момент до 9,0 кН·м падение веса после 39 оборотов и момента. Проверка веса наверх увеличение веса 0,5-1,0 тн, то есть 57-58 тн. Подъем бурильного инструмента с разборкой и выбросом на мостки. После подъема 13 свечей (244 м) во время движения инструмента вверх падение веса с 49 тн до 13 тн; сборка и спуск СБТ 89 на «голову», на 2,5 м ниже предыдущего, наворот, докрепление до 8,5 кН·м. Вес наверх сначала с затяжками до 70-73 тн (при остановке движения вес постепенно падает, после подъема 6 м вес стал свой, дальше на подъем свой вес 56-57 тн, контрольная проверка с вращением вниз. Подняли с разборкой и выбросом на мостки. СБТ 73 вторая и третья снизу деформированы (изогнутость) последняя почти ровная. Захватили 17 труб НКТ 60 длиной 169,82 м. «Голова» аварийной трубой находится на глубине 2651 м, 
представлена муфтой диаметром 73 мм. НКТ 60 первые 3 трубы сильно деформированы (гнутые, первая винтом), 6-я труба слегка деформирована, последняя 17-я труба ниппель прорезан на глубину 50 мм.

Перешли на левый инструмент: перевернули квадрат.

Собрали КНБК: колокол К80-55/110 Л - Мз76 Л - 0,52 м + СБТ 73 ×9,19 ЗН 95 3-76 Л 2244,28 м + переводник Мз102 Л×Н376 Л - 0,31 м + СБТ 89 ЗН 121 3-102 Л - 400 м.

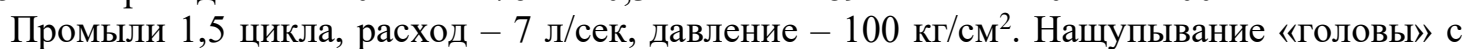

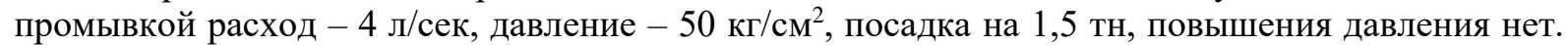
Проверка веса без промывки: вверх $43 \mathrm{TH}$, вниз 30,5 тн, при вращение 35,5 тн, момент холостой $3,0 \mathrm{\kappa H} \cdot \mathrm{м}$. Наворот на «голову» с нагрузкой $0,5-1 \mathrm{TH}$, до момента $4 \mathrm{\kappa H} \cdot \mathrm{м}$. Подтянули до $36 \mathrm{TH}$ сделали 3 оборота на отворот, возврат 3 оборота, момент -4 кН·м, подтянули до 38 тн сделали 3 оборота на отворот возврат 3 оборота, момент $-4 \mathrm{\kappa H} \cdot$ м. Подтянули до 40 тн на 3 оборота произошел срыв, момент - 3 кН·м. При движении вверх свой вес 43 тн. Повтор операции с нагрузкой до 2 тн, и с натяжкой до 38 тн, момент 3 кН·м, вес вверх 43 тн, повторили 3 попытки наворота, момент $-3,5$ кН·м, посадки нет - возможно прошли мимо головы спустили на 0,4 м ниже. Вес вверх 43 тн - свой. Подняли инструмент, результат отрицательный. Колокол К8055/110 Л работал на «голове» есть две прорези под муфту НКТ 60 глубиной 15 мм.

Собрали КНБК: К 95 - 60/122 Л Мз -86 Л - 0,77 м + переводник Мз76 Л×Нз86 Л - 0,3 м + СБТ $73 \times 9,19$ ЗН 95 3-76 Л - 2244,28 м + переводник Мэ102 Л×Нз76 Л - 0,31 м + СБТ 89 ЗН 121 3-102 Л - 402,46 м + квадрат 3 м.

Взвешивание: при движении вверх 41,5 - 42,0 тн, вниз 29,0 - 29,5 тн, при вращении 34,8 тн, момент холостой 3,2 кН·м. С вращением опустились на «голову», с постепенной разгрузкой до 2 тн. Соединились с «головой» до повышения момента 4,5 кН·м. Подтянули инструмент до $47 \mathrm{TH}$, дали 4 оборота на отворот, вес упал до 42 тн, момент до 5,2 кН·м, возврат пружины 2 оборота. Подтянули до 48 тн, дали 4 оборота на отворот, вес упал до 45 тн, момент до $5,2 \mathrm{\kappa H}$ м, возврат пружины 2 оборота. Подтянули до 50 тн, дали 8 оборотов на отворот, момент до 5,2 кН·м, резкое падение веса до 36 тн и момента. Проверка вес вверх свой 41,5 42 тн, нащупали «голову» без вращения с разгрузкой до 1 тн. Приподнялись над «головой» на 1,5 м и проверили вращением. Вошли ниже головы на 0,7 м, вес свой при холостом вращение 34,8 тн, момент холостой 3,2 кН·м. Остановили вращение и еще на 0,6 м спустились вес 29,0 29,5 тн, всего ниже головы прошли 1,3 м. На подъем затяжек нет, вес 41,5-42,0 тн. Подняли инструмент, «голова» находится на глубине 2671,3 м, представлена муфтой диаметром 73 мм.

Собрали КНБК: К 95 - 60/122 Лев Мз -86 Л - 0,77 м + переводник Мз76 Л×Н386 Л 0,3 м + СБТ $73 \times 9,19$ ЗН 95 3-76 Л - 2252,68 м + переводник Мз102 Л×Нз76 Л - 0,31 м + СБТ 89 ЗН 121 3-102 Л - 414,66 м + квадрат 3 м. Спустили до глубины 2520 м, промыли скважину. Спустили на глубину 2670 м.

Взвешивание: при движении вверх 44,6 тн, вниз $32-32,5$ тн, при вращении 36,7 тн, момент холостой 3,2 кН·м. С вращение подошли на «голову», с постепенной разгрузкой до 2 тн соединились с головой до повышения момента 4,0 кН·м. Подтянули инструмент до 48 тн, дали 4 оборота на отворот, вес упал до 44 тн, момент до 5,0 кН.м, возврат пружины 3,5 оборота. Подтянули до 49 тн, дали 3 оборота на отворот, вес упал до 47 тн, момент до 5,0 кН·м, возврат пружины 3 оборота. Подтянули до 50 тн, дали 4 оборота на отворот, момент до 5,0 кН·м, резкое падение веса до 36 тн и момента. Проверка вес вверх свой 44,0 - 44,5 тн. Нащупали «голову» без вращения с разгрузкой до 1,5 тн. Приподнялись над «головой» на 1,5 м и проверка с вращением, при подходе на «голову» начал расти момент с холостого и выше с разгрузкой до $1,5-2$ тн и максимальный момент до 5,5 кН·м. Подтянули до 50 тн и отвернулись на восьмом обороте с максимальным моментом 5,6 - 5,7 кН·м. Проверка прибавление веса - вес от 44,6 45,1 (от 0 до 0,5 тн собственный вес на подъем). Проверка «головы» разгрузкой, пасадка на 1,5 тн, на том же месте, где отворачивались. Проверка с вращение на том же месте, момент холостой при разгрузке до 2 тн. Подъем.

Подняли 10 труб НКТ 60 длиной 102 м. «Голова» находится на глубине 2773,3 м, представлена муфтой диаметром 73 мм.

Собрали КНБК: ФК - 96 Л - 0,59 м + СБТ 73 Л - 2261,08 м + переводник Мз102 Л×Н376 Л $-0,31$ м + СБТ 89 Л - 422,86 м.

Спускали с периодическими промывками и прогревом скважины и инструмента. Спустили на «голову» хвостовика до глубины 2689 м. С промывкой и вращением вошли в 
«голову», посадки нет. Проработка в интервале 2689 - 2744 м. Режим: расход - 7 л/сек,

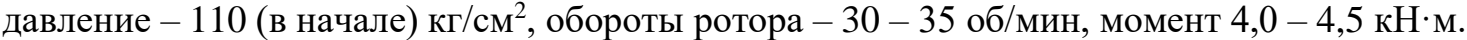

Проработка в интервале $2744-2773,3$ м, расход - 7 л/сек, давление - 160 - 170 (в

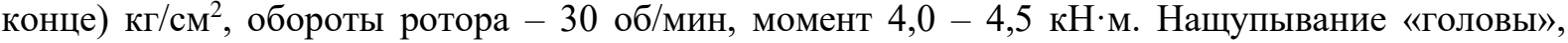
10 об/мин рост момента до $5 \mathrm{\kappa H} \cdot$ м, разгрузка 2 тн. Промывка 1,5 цикла. Подняли, осмотрели ФК - 96 Л, есть следы посадки на муфту НКТ 60.

Собрали КНБК: труболовка внутренняя освобождающаяся ТВМ 1 - 60Л Мз - 76Л диапазон захвата $47-55$ мм - 0,89 м + СБТ $73 \times 9,19$ ЗН 95 3-76 Л - 2244,28 м (121 свеча) + переводник Мз102Л×Нз76 Л - 0,31 м + СБТ 89 ЗН 121 3-102 Л - (43 одиночки). Спуск с поинтервальной промывкой с прогревом бурильного инструмента и скважины. Спуск до глубины 2765 м. Взвешивание: вверх - 48 тн, вниз - 32 тн. Промывка 5 - 6 л/сек, давление 150 - 180 кг $\mathrm{cm}^{2}$. С промывкой $2,0-2,5$ л/сек вошли в «голову», повышение давления от 50 до

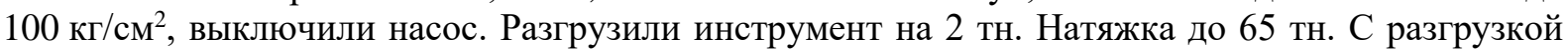
до 57 тн отворот, на 17 обороте при моменте 7,5 кН·м отвернулись. Прибавление веса нет - при движении вверх 48 тн. Подняли 1 трубу НКТ 60 длиной 10,4 м. «Голова» находится на глубине 2784 м. Во время разборки произошел слом труболовки на уровне подвижного «сухаря» (все части труболовки на поверхности).

Собрали КНБК: ТВП - 60 Л Мз - 76 Л диапазон захвата $49-55$ мм - 0,64 м + переводник Мз76 Л×Нз73 Л - 0,21 м + СБТ $73 \times 9,19$ ЗН 95 3-76 Л - 2244,28 м (121 свеча) + переводник Мз102 Л×Нз76 Л - 0,31 м + СБТ 89 ЗН 121 3-102 Л - 536 м (44 трубы - одиночки). Спуск с поинтервальной промывкой с прогревом бурильного инструмента и скважины. Взвешивание: вверх 44 тн, вниз 29,5-30 тн. Промывка расход - 5 л/сек, давление 130 -

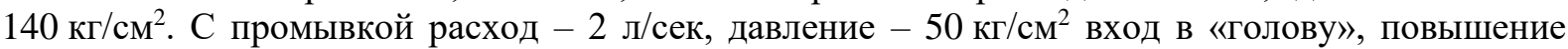
давления до 90 кг $/ \mathrm{cm}^{2}$, отключение насоса. Разгрузка 2 тн, подъём, вес свой 44 тн. Аналогичная попытка повторялась несколько раз увеличивая разгрузку до 4,5 тн. Вес вверх свой 44 тн.

Подняли инструмент - результат отрицательный. Собрали КНБК: овершот ОВ - 95Л спиральный захват 73 мм (2-7/8) Мз-73 - 0,67 м + переводник Мз76Л×Нз73Л - 0,21 м + СБТ 73 $\times$ 9,19 ЗН 95 3-76 Л - 2244,28 м (121 свеча) + переводник Мэ102 Л×Нз76 Л - 0,31 м + СБТ 89 ЗН 121 3-102 Л - 536 м (44 одиночки).

Произвели взвешивание: вверх 44 тн, вниз 29,5 - 30 тн. Промывка расход - 5 л/сек, давление 90 - 100 кг см² $^{2}$ Взвешивание: вверх - 44 - 44,5 тн (изредка до 45), вниз - 29,5 - 30 тн, момент холостой $-3,5$ кН·м. Захват аварийной головы с вращением $3-4$ об/мин до разгрузки 2 тн. С выключенным ротором разгрузка до 5,5 тн (24 тн). Проверили захват с натяжкой до 60 тн (с выдержкой 10 мин). Разгрузили до 50 тн (5 тн ССВ вверх), дали 5 оборотов - вернулось 4 оборота, натяжка до 60 тн, разгрузка до 50 тн, дали 6 оборотов - вернулось 4 оборота, натяжка до $55 \mathrm{TH}$, разгрузка до 49, дали 6,5 оборотов - вернулось 5 оборотов, натяжка до $55 \mathrm{TH}$, разгрузка до $48 \mathrm{TH}$, отворот - на 10 обороте при максимальном моменте до $8 \mathrm{\kappa H} \cdot \mathrm{M}$, резкое падение веса до 38 тн и момента до 0 кН·м. Проверка веса вверх 45 - 45,6 тн (стабильно). Подняли 10 труб НКТ 60 длиной 103 м. Голова находится на глубине 2887 м, представлена муфтой НКТ 60 диаметром 73 мм. Осмотр овершота ОВ-95 Л - сломан спиральный захват 73 мм (2-7/8). Решили прорайбировать диаметром 96 мм интервал $2784-2887$ м. Произвели смену талевого каната.

Собрали КНБК: ФК - 96Л - 0,59 м + СБТ 73 Л - 2252,58 м + переводник Мз102Л×Н376 Л - 0,31 м + СБТ 89Л - 633,88 м. Спуск до глубины 2784 м. Проработка интервала $2784-2887$ м.

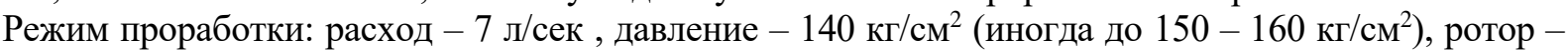
$30-36$ об/мин, момент $-4-5$ кН·м. Промывка 1,5 цикла. Подняли и разобрали КНБК.

Собрали КНБК: ТВМ 1 - 60Л Мз - 76 Л диапазон захвата $47-55$ мм $-0,89$ м + СБТ 73 Л - 2260,98 м + переводник Мз102Л×Нз76 Л - 0,31 м + СБТ 89Л - 621,7 м.

Спустили с промежуточными промывками. Взвешивание: вверх 47,5 тн, вниз 30 тн. Промыли над «головой»: расход - 5 л/сек, давление 70 кг $/ \mathrm{cm}^{2}$. С промывкой расходом 2 л/сек и давлением 50 кг $/ \mathrm{cm}^{2}$ накрылись с разгрузкой 4,5 тн, повышения давления нет. Остановили циркуляцию, подтянули вверх с натяжкой 63 тн, выдержка - падения веса не наблюдалось. Разгрузили до 51,5 тн (4 тн ССВ вверх). Отворот, при 18 оборотах, момент максимальный 7,5 кН·м, падение момента и веса до 37,5 тн. При движении вверх вес 47,8 - 48,5 тн. Подняли НКТ 60 - 6 труб длиной 60,6 м. «Голова» находится на глубине 2947,6 м, представлена муфтой диаметром 73 мм. 
Собрали КНБК: ТВМ 1 - 60Л Мз - 76 Л диапазон захвата $47-55$ мм - 0,89 м + СБТ 73 Л - 2260,98 м + переводник Мз102Л×Нз76 Л - 0,31 м + СБТ 89Л - 56 труб (682,7 м).

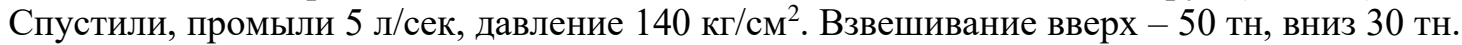
С промывкой расходом 2 л/сек и давлением 40 кг/см ${ }^{2}$, накрылись с разгрузкой $4,5 \mathrm{TH}$, повышения давления нет. Остановили циркуляцию, подтянули вверх с натяжкой $66 \mathrm{TH}$, выдержка - падения веса не наблюдалось. Разгрузили до 53,5 тн (3,5 тн ССВ вверх). Произвели отворот, на 28 обороте, момент максимальный $8,0 \mathrm{\kappa H} \cdot \mathrm{м}$, падение момента и веса до $38,5 \mathrm{TH}$. При движении вверх вес 50 (свой) тн. Подняли НКТ 60 - 4 трубы длиной 40,2 м. «Голова» находится на глубине 2987,8 м, представлена муфтой диаметром 73 мм.

Собрали КНБК: ТВМ 1 - 60Л Мз - 76 Л диапазон захвата $47-55$ мм - 0,89 м + СБТ 73 Л - 2252,58 м + переводник Мз102Л×Нз76 Л - 0,31 м + СБТ 89Л - 60 труб 731,4 м. Спуск с промывкой 5 л/сек, давление 140 кг/см². Взвешивание вверх - 55 тн, вниз 34 тн. С промывкой расходом 2 л/сек и давлением 60 кг $/ \mathrm{cm}^{2}$, накрылись с разгрузкой 4,5 тн, повышение давления - 70 кг $/ \mathrm{cm}^{2}$. Остановили циркуляцию, подтянули вверх с натяжкой 72 тн, выдержка падения веса не наблюдалось. Разгрузили до 60,0 тн (5 тн ССВ на верх). Произвели отворот, на 23 обороте, момент максимальный 8,5 кН·м, падение момента и веса до 44,0 тн. При движении вверх вес 55 тн (свой). Подняли НКТ 60 - 3 трубы длиной 30,6 м. «Голова» находится на глубине 3018,4 м, представлена муфтой диаметром 73 мм.

Собрали КНБК: ТВМ 1 - 60Л Мз - 76 Л диапазон захвата $47-55$ мм - 0,89 м + СБТ 73 Л - 2260,98 м + переводник Мз102Л×Н376 Л - 0,31 м + СБТ 89Л - 62 трубы - 755.8 м.

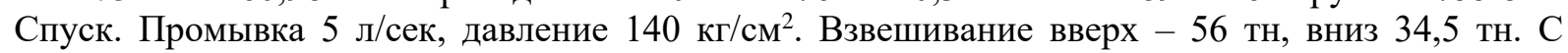

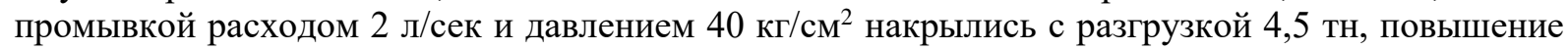
давления нет. Остановили циркуляцию, подтянули вверх с натяжкой 72,5 тн, выдержка падение веса не наблюдалось. Разгрузка до 60,5 тн (4,5 тн ССВ вверх). Отворот, на 19 обороте, момент максимальный до 8,0 кН·м, падение момента и веса до 44,0 тн. При движении вверх вес 57,5 (1,5 тн ССВ вверх) тн. Подняли НКТ 60 - 13 труб длиной 133,07 м. «Голова» находится на глубине 3151,5 м, представлена муфтой диаметром 73 мм. В скважине осталось 18 труб НКТ 60 длиной 182 м КНБК 6,5 м ( обратный клапан $\mathrm{M}_{\text {нкт }} 60 \times \mathrm{H}_{\text {нкт }} 60$ (длина 0,45 м $\varnothing_{\text {нар }}-89$ ), переводник

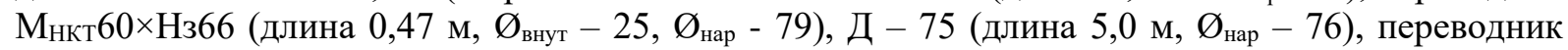
Н366×Нз66 (длина 0,47 м, Øвнут $-25, \varnothing_{\text {нар }}-79$ ), долото У-954 Рис (выс 0,13 м, Ø нар -95 ).

Сборка КНБК: ТВМ 1 - 60Л Мз - 76 Л диапазон захвата $47-55$ мм - 0,89 м + СБТ 73 Л - 2244,28 м + переводник Мз102Л×Н376 Л - 0,31 м + СБТ 89Л - 74 трубы - 902.06 м. Спуск.

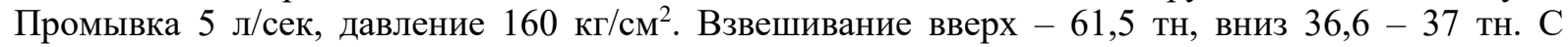
промывкой расходом 2 л/сек и давлением 40 кг $\mathrm{cm}^{2}$, накрылись с разгрузкой 4,5 тн, повышение

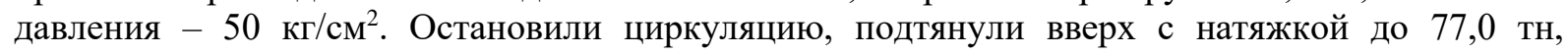
выдержка - падение веса не наблюдалось. Разгрузка до 66,0 тн (4,5 тн ССВ вверх). Отворот, на 34 обороте, момент максимальный до $10,0-10,5$ кН·м, падение момента и веса до 46,0 тн. При движении вверх вес 61,0 - 61,5 (собственный вес вверх) тн. Подняли НКТ 60 - одну трубу длиной 10,17 м. «Голова» находится на глубине 3161,7 м, представлена муфтой диаметром 73 мм. В скважине осталось 17 труб НКТ 60 длиной 171,8 м КНБК 6,5 м (обратный клапан

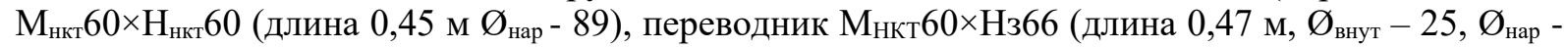
79), Д - 75 (длина 5,0 м, Ø нар - 76), переводник Нз66×Н366 (длина 0,47 м, Ø внут $-25, \varnothing_{\text {нар }}-79$ ), долото У-954 Рис (выс 0,13 м, Øнар - 95). На труболовке сломан поводок (стержень) поддерживающий подвижную плашку («сухарь»), все части труболовки на поверхности (слом возможно произошел при резком сбросе момента после отворота). На муфте НКТ труболовкой зажата резина (расслоена резина от рукава высокого давления). Множество кусков от пластика на муфте НКТ, максимальным размером $4 \times 4 \times 4$ мм.

Собрали КНБК: колокол гладкий КГ $80-65$ Л - 0,66 м + СБТ 73 Л - 2244,28 м + переводник Мз102Л×Н376 Л - 0,31 м + СБТ 89Л - 75 труб - 914.25 м. Спуск инструмента и

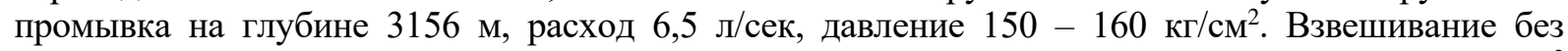
промывки: вверх - 58 тн, вниз - 33-33,5 тн. С промывкой 3 л/сек при давление $60 \mathrm{\kappa r} / \mathrm{cm}^{2}$ накрылись, давление выросло до 80 кг $/ \mathrm{cm}^{2}$, оторвались от забоя выключили насос. Продули монифольд. Разгрузили инструмент быстрым движением вниз, накрылись на «голову» с разгрузкой до 0 тн. Расхаживание инструментом натяжкой до $60-61$ тн и разгрузкой до 0 тн. Вытяжка 3,8 м. Произвели эту операцию периодически выдерживая 1-2 минуты, 25 раз. Движения инструмента не вверх, не вниз нет. Отворот с натяжкой вверх 59,5 тн, 37 оборотов. Вес 
постепенно падал до 44 тн. Момент до $5-5,2$ кН·м. Скачков никаких не произошло. При проверке веса вверх 60 тн (2 тн ССВ вверх). Подняли НКТ 60 - 15 труб длиной 152,3 м. «Голова» находится на глубине 3314,0 м, представлена ниппелем диаметром 60 мм. В скважине осталось 2

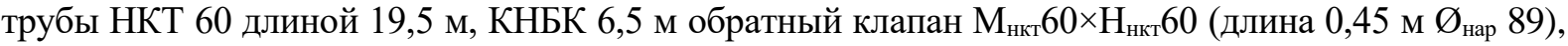

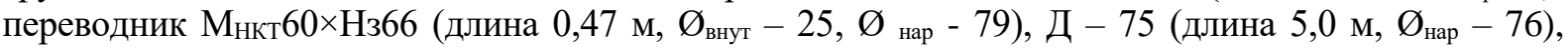
переводник Нз66×Нз66 (длина 0,47 м, Ø внут $-25, \varnothing_{\text {нар }}-79$ ), долото У-954 Рис (выс 0,13 м, Øнар -95 ).

Сборка КНБК: колокол гладкий КГ $70-55$ Л - 0,66 м + СБТ 73 Л - 2252,58 м + переводник Мз102Л×Нз76 Л - 0,31 м + СБТ 89Л - 87 труб - 1060.53 м. Спуск. Проработка (промывка с вращением) с глубины 3161м до глубины 3312 м, расход - 5 - 6 л/сек, давление -

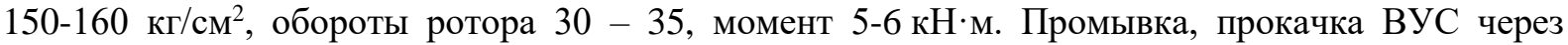
скважину V -6 м $^{3}, \mathrm{~T}-80$ сек. Взвешивание без промывки: вверх - $62-62,5$ тн, вниз - 35-

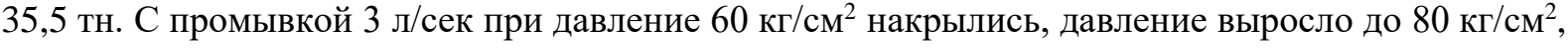
отключили насос, стравили избыточное давление, разгрузили инструмент вниз, накрылись на голову с разгрузкой до 0 тн. Расхаживание инструмента натяжкой до $63-64$ тн и разгрузкой до 0 тн. Вытяжка 3,8 м. Произвели эту операцию периодически выдерживая 1-2 минуты, 10 раз. Движения инструмента не вверх, не вниз нет. Отворот с натяжкой вверх 63,5 тн, 30 оборотов, вес постепенно падал до 46,7 тн. Момент до 6,5 - 7 кН·м, резкое падение момента до 5,5 кН·м. При проверке веса на верх $62-62,5$ тн (свой вес вверх). Подняли - результат отрицательный.

Сборка КНБК: колокол К 70-52 Л Мз-66 Л (Ø нар 90 мм) - 0,52 м + переводник Мз76Л×Нз66Л (Ø вн 24 мм, Ø нар 95 мм) - 0,24 м + СБТ 73 Л - 2252,58 м + переводник Мз102Л×Нз76 Л - 0,31 м + СБТ 89Л - 87 труб - 1060.53 м.

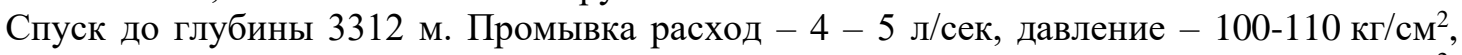
обороты ротора $10-121$, момент $5 \mathrm{\kappa H} \cdot \mathrm{M}$ (без вращения рост давления до $150 \mathrm{\kappa} / \mathrm{cm}^{2}$, циркуляция прекращается). Остановка циркуляции, смена ведущей трубы на СБТ 89 Л, взвешивание вверх 58 тн, вниз 33,5 тн. Наворот на голову с моментом до 9,5 кН·м. проверка веса с натяжкой до 70 тн. Расхаживание с натяжкой от 68 до 74 тн $(10-16$ тн ССВ вверх) 25 раз. Отворот при весе 44 тн с моментом до $10 \mathrm{\kappa H} \cdot \mathrm{м}$, падение до 5,5 кН·м, проверка веса верх - вес до 62- 65 тн и падение до 58 тн. Разгрузка вниз, с разгрузкой до 30 тн повторно отворачивались с максимальным моментом до 9,5 кН·м., падение до 6 кН·м, на подъем вес 62 65 (4-7 тн ССВ вверх) тн. Подняли НКТ 60 одну трубу длиной 9,9 м. «Голова» находится на глубине 3323,9 м, представлена муфтой диаметром 73 мм. На верхнем ниппеле НКТ 60 есть две вмятины (возможно от гладкого колокола). В скважине осталась одна труба НКТ 60 длиной 9,6 м, КНБК 6,5 м ( обратный клапан $\mathrm{M}_{\text {нкт }} 60 \times \mathrm{H}_{\text {нкт }} 60$ (длина 0,45 м $\varnothing_{\text {нар }}-89$ ), переводник

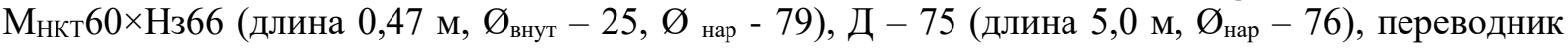
Нз66×Нз66 (длина 0,47 м, Ø внут $-25, \varnothing_{\text {нар }}-79$ ), долото У-954 Рис (выс 0,13 м, Øнар -95 ).

Решено дальнейшие работы производить обурником. В скважине осталась одна труба НКТ 60 длиной 9,6 м, КНБК 6,5 м (обратный клапан $\mathrm{M}_{\text {нкт }} 60 \times \mathrm{H}_{\text {нкт }} 60$ (длина 0,45 м $\varnothing_{\text {нар }} 89$ (состоит снизу вверх переводник $\mathrm{H}_{\text {нкт }} 60 \times \mathrm{H}_{\text {нкт }} 73$, клапан $\mathrm{M}_{\text {нкт }} 73 \times \mathrm{H}_{\text {нкт }} 73$, муфта НКТ $73 \mathrm{M}_{\text {нкт }} 73 \times \mathrm{M}_{\text {нкт }} 73$, переводник $\mathrm{H}_{\text {нкт }} 73 \times \mathrm{M}_{\text {нкт }} 60$ ), переводник $\mathrm{M}_{\text {нкт }} 60 \times \mathrm{H} 366$ (длина 0,47 м, $\varnothing_{\text {внут }}-25, \varnothing_{\text {нар }}-79$ ), Д - 75 (длина 5,0 м, Ø нар -76 ), переводник Нз66×Нз66 (длина 0,47 м, Ø внут $25, \varnothing_{\text {нар }}$ - 79), долото У-954 Рис (выс 0,13 м, Ø нар - 95). Характеристика обурника: наружный диаметр переводника - 93 мм, внутренний миним - 40 мм (изготовлен из отработанного колокола КГ 70-55Л), присоединительная резьба к инструменту Мз76Л, к трубе НКТ 89 - 80,8 ленточная шаг 6 ниток на дюйм длина резьбы - 75 мм, конусность 0 градусов 55 минут; тело обурника НКТ 89×5,5 (заводские резьбы срезаны) внутренний диаметр номинальный - 76 мм; вооружение 8 зубьев высотой 20 мм, напайка сармайт, внутренний диаметр на зубьях -75 мм, наружный диаметр 95 мм. Общая длина - 9,23 м, рабочая длина обурника 9,0 м.

Сборка КНБК: обурник ОБ 95×75 Л - 9,23 м + СБТ 73 Л - 2252,58 м + переводник Мз102Л×Нз76 Л - 0,31 м + СБТ 89Л - 87 труб - 1060,53 м. Спуск до глубины 3310 м с промежуточной промывкой на «голове» хвостовика. Промывка с проработкой интервал 3310,03323,9 м до полного устранения посадок затяжек до 5 тн, повышенного момента до 7,5 кН·м (рабочий момент 5,0 - 5,5 кН·м). Обуривание «головы» на 0,1 м постоянным подъемом инструмента и расхаживанием (при входе на голову повышение давления на $10 \mathrm{\kappa r} / \mathrm{cm}^{2}$, роста момента не наблюдалось, затяжек и посадок нет). После согласования с заказчиком, обуривание НКТ 60 по 0,1 м с подъемом и расхаживанием после обуривания 0,5 м на длину квадрата. Обурили на длину квадрата в интервале 3323,9 - 3330,0 м (6,1 м). При расхаживание посадок на 
«голову» нет. Промывка после обуривания. Рабочий режим при промывке и обуривание: расход -

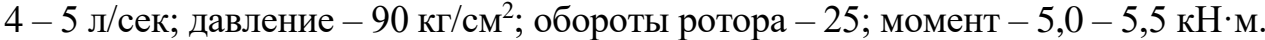

Подъем инструмента, осмотр обурника: сразу после верхнего переводника обурника имеется царапина в виде спирали на длину обурника 1,3 м, глубина максимальная 1 мм, ширина 5 мм; вооружение обурника целое - сколы, сломы зубьев отсутствуют, диаметр наружный не потерян (95 мм). Заход обурника отшлифован, что указывает на вход в «голову» НКТ 60.

Сборка КНБК: ТВМ 1 - 60Л Мз - 76 Л диапазон захвата $47-55$ мм - 0,89 м + СБТ 73 Л - 2250,98 м + переводник Мз102Л×Н376 Л - 0,31 м + СБТ 89Л - 87 труб - 1060 м. Промывка в режиме 5 л/сек, давление 100 атм. Взвешивание без промывки: вверх 66,5 - 67 тн, вниз 37,5 тн. С промывкой 3 л/сек при давление 30 атм спуск на нащупывание, «головы» на глубине 3324 м нет. Нарастили, с промывкой спустились до глубины 3346 м - «голову» не нащупали. Подъем и разборка КНБК. Решили спустить НКТ 73, прошаблонировать до глубины 3813 м, если оставшаяся КНБК длиной 16,1 м находится не на забое, то протолкнуть на забой 3829 м. Промыться, заменить раствор на техническую воду, приподняться до устья. Завезли НКТ 73. Собрали КНБК: ловушка для сваба, переводник $\mathrm{M}_{\text {нкт }} 73 \times \mathrm{H}_{\text {нкт }} 73$ (Ø внут 49 мм $\emptyset_{\text {нар }} 87$ мм $)-0,21$ м + НКТ 73 гладкая - 1205,39 м + переводник $\mathrm{M}_{\text {нкт }} 78$ (высадка) $\times \mathrm{H}_{\text {нкт }} 73$ (гладкая) (Ø внут 62 мм $\varnothing_{\text {нар }} 95$ мм) - 0,16 м + НКТ 73 высадка остальное. Спуск инструмента и промывка на глубине 2685 м: расход 5 - 6 л/сек, давление 25 - 30 атм. Спустили до глубины 3307,82 м, промыли: расход 5 - 6 л/сек, давление 25 - 30 атм. Спуск до глубины 3551 м: расход 5 - 6 л/сек, давление 25 - 30 атм. Спустили до глубины 3802 м, посадка до 5 тн. Дали промывку приподнявшись до 3800 м, циркуляция скачкообразная давление до 100 - 110 атм. Приподнялись до глубины 3797 м, восстановили циркуляцию стабильную, давление 35-40 атм, при расходе 5-6 л/сек. После 1 часа промывки убрали одну НКТ 73 - инструмент на глубине 3795 м. Взяли квадрат восстановили циркуляцию и с промывкой пошли вниз давление 35-40 атм. На глубине 3801,2 м рост давления (допускали рост давления до 100 атм). Приподнялись до 3795 м, расхаживание, циркуляция есть - давление до 70 атм. Восстановили нормальную циркуляцию давление 35 40 атм, при расходе 5 - 6 л/сек. Промыли три цикла, подняли КНБК с выбросом инструмента на мостки. Авария ликвидирована. На ликвидацию аварии затрачено 745 часов (31 сутки).

Суммарное время на ликвидацию двух аварий составило 812 часов. Этого времени достаточно для того, чтобы пробурить один боковой ствол. И это еще не считая материальных затрат.

Представленный в работе материал по бурению боковых стволов скважин демонстрирует сложность и ответственность за каждое действие, при которым возможно не только достичь желаемый результат в процессе бурения и работ по ликвидации аварии, но и при отклонении от предусмотренного плана или программы работ возможно и усложнить положение. Данный фактический материал может быть достаточно наглядно использован в учебном процессе, при подготовке специалистов соответствующего профиля.

\section{ЛИТЕРАТУРА}

1. Антонов К.В. Бурение скважин / сост. К.В. Антонов, Р.А. Валиуллин, И.Г. Низаева / под ред. канд. техн. наук, доцента К.В. Антонова. - Уфа: РИЦ БашГУ, 2018. - 344 с.

2. Калинин А.Г. Бурение нефтяных и газовых скважин: Справочник / А.Г. Калинин, Б.А. Никитин, К.М. Солодкий, Б.З. Султанов. - М.: Недра, 1997. - 618 с.

3. Оганов С.А. Предупреждение аварий и осложнений при бурении горизонтальных скважин // Строительство нефтяных и газовых скважин на суше и на море./ С.А. Оганов. - М.: ВНИИОЭНГ. 1995. - № 3. - C. 11-14.

4. Правила безопасности в нефтяной и газовой промышленности. - М.: Госгортехнадзор России, 1993.- $104 \mathrm{c}$

5. Пустовойтенко И. П. Предупреждение и ликвидация аварий в бурении / И.П. Пустовойтенко. - М.: Недра, 1988. - 279. 